\title{
Koreksi Geometrik Pemetaan Tataguna Lahan di Sekitar Calon Tapak PLTN Kalimantan Barat
}

\author{
Heri Priyanto*1, Mudjiono², Sutarto Yosomulyono ${ }^{1}$ \\ ${ }^{1}$ Fakultas Teknik, Universitas Tanjungpura, Jl. Prof. Dr. Hadary Nawawi - Kota Pontianak, Indonesia \\ ${ }^{2}$ Pusat Kajian Sistem Energi Nuklir, BATAN, Jl. Kuningan Barat, Mampang Prapatan, Jakarta, Indonesia
}

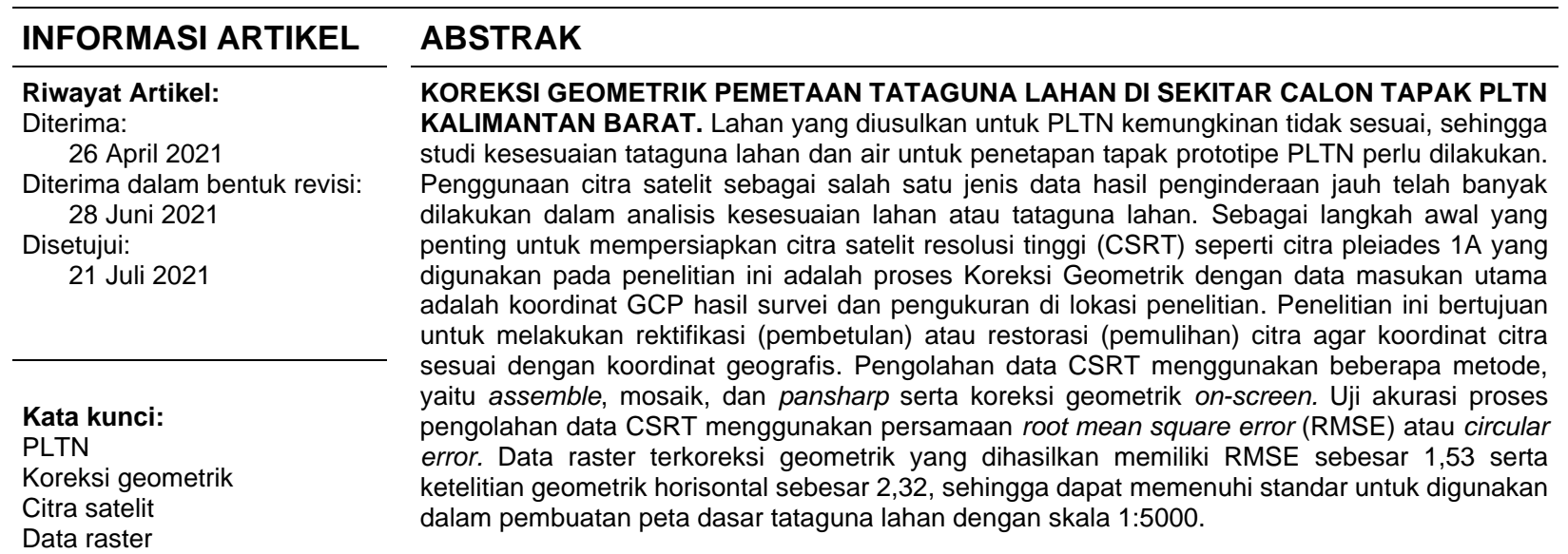

SIG

\begin{abstract}
GEOMETRIC CORRECTION ON LAND USE MAPPING AROUND CANDIDATE SITE OF NPP WEST KALIMANTAN. The proposed land for Nuclear Power Plant (NPP) may not be suitable, so it is necessary to carry out a study on the suitability of land use and water for the determination of the NPP prototype site. The use of satellite imagery as a type of remote sensing data has been widely used in land suitability or land use analysis. As an important first step to prepare highresolution satellite images such as the Pleiades $1 \mathrm{~A}$ image used in this study is the Geometric Correction process with the main input data being the GCP coordinates of the survey results and measurements at the research location. This research aims to rectify or restore the image so that the image coordinates match the geographical coordinates. High-resolution satellite images data processing uses several methods, namely assemble, mosaic, and pansharp as well as on-screen geometric correction. Test the accuracy of high-resolution satellite images data processing using the root mean square error (RMSE) or circular error equation The resulting geometrically corrected raster data has an RMSE of 1.53 and a horizontal geometric accuracy of 2.32, so that it can meet the standards for use in making basic land use maps with a scale of 1:5000.

Keywords: NPP, geometric correction, satellite imagery, raster data, GIS
\end{abstract}

(C) 2021 Jurnal Pengembangan Energi Nuklir. All rights reserved

\section{PENDAHULUAN}

Dalam Rencana Pembangunan Jangka Menengah Daerah (RPJMD) Provinsi Kalimantan Barat Tahun 2018-2023, Pembangkit Listrik Tenaga Nuklir (PLTN) yang merupakan sumber energi baru dan energi terbarukan (EBT) telah diusulkan sebagai salah satu jenis pembangkit listrik untuk menambah pasokan listrik di wilayah Kalimantan Barat, maka perlu dilakukan evaluasi tapak rencana pembangunan prototipe PLTN di wilayah tersebut.

"Penulis korespondensi.

E-mail: heripriyanto@informatika.untan.ac.id
Dalam Peraturan Badan Pengawas Tenaga Nuklir No. 4 Tahun 2018, bahwa keamanan dan keselamatan tapak PLTN harus memenuhi Ketentuan Keselamatan Evaluasi Tapak Instalasi Nuklir [1]. Dalam tahapan konstruksi dan operasi, PLTN dapat memberikan dampak potensial pada lingkungan, baik pada sistem ekologi, penggunaan lahan dan air, udara, estetika dan sosio ekonomi. Lahan yang diusulkan untuk PLTN kemungkinan tidak sesuai, sehingga studi kesesuaian tataguna lahan dan air untuk penetapan tapak prototipe PLTN perlu dilakukan.

Penggunaan data penginderaan jauh dan SIG (Sistem Informasi Geografis) telah banyak 
dilakukan untuk analisis terhadap pemilihan lokasi suatu industri termasuk dalam kesesuaian lahan untuk tapak prototipe PLTN [2]. Aplikasi SIG sangat tergantung pada data geospasial.

Hasil kajian terdahulu berhasil diidentifikasi bahwa, penggunaan lahan di site area (radius $1 \mathrm{~km}$ ) calon tapak adalah untuk pemukiman penduduk seluas $53.176 \mathrm{~m}^{2}$, lahan terbuka $175.021 \mathrm{~m}^{2}$, perkebunan $2.001 .696 \mathrm{~m}^{2}$, perairan darat $56.718 \mathrm{~m}^{2}$, dan laut $953.389 \mathrm{~m}^{2}$. Secara umum, dapat diasumsikan bahwa dengan dibangunnya PLTN di masa mendatang, peruntukkan lahan dominan (perkebunan) akan berubah ke arah pembangunan industri, sehingga konversi pemanfaatan lahan akan menyebabkan tumbuh dan berkembang sarana dan prasarana untuk perkantoran, perumahan, pendidikan, kesehatan, peribadatan, pemukiman, kemananan dan sarana pendukung lainnya [3][4].

Data citra satelit, sebagai salah satu data hasil penginderaan jauh, yang digunakan sebagai data pendukung pada penelitian ini, adalah data citra satelit resolusi tinggi (CSRT) dari satelit Pleiades 1A dengan ketelitian pankromatik $0,5 \mathrm{~m}$ dan ketelitian multispektral $2 \mathrm{~m}$ [5]. Sebagai tahap persiapan yang penting, perlu dilakukan proses koreksi geometrik terhadap citra tersebut untuk mendapatkan ketelitian geometrik [6], sehingga dapat diperoleh data raster dengan ketelitian yang baik untuk digunakan pada aplikasi SIG. Penelitian ini bertujuan untuk melakukan rektifikasi (pembetulan) atau restorasi (pemulihan) citra agar koordinat citra sesuai dengan koordinat geografis pada lokasi penelitian.

\section{KOREKSI GEOMETRIK CITRA SATELIT}

\subsection{Citra Satelit Resolusi Tinggi (CSRT)}

Citra satelit adalah salah satu hasil dari teknologi penginderaan jauh yang menggunakan satelit sebagai wahana perekaman kenampakan pada permukaan bumi [7].

Resolusi spasial merupakan kemampuan untuk menampakkan dua obyek yang berdekatan secara terpisah. Resolusi spasial dipengaruhi oleh piksel citra tersebut. Semakin banyak piksel dan ukuran piksel yang kecil memberikan detail yang lebih baik, karena setiap piksel akan mewakili informasi suatu citra. Semakin besar matriks piksel maka akan memberikan resolusi spasial yang lebih baik [8]. Resolusi spasial dapat disebabkan juga oleh blur akibat faktor geometris, misalnya karena ukuran fokus tabung, difusi cahaya pada reseptor, bukaan diafragma, dan pergerakan. Dalam diagnostik pencitraan digital, resolusi spasial 2,5-5,0 $\mathrm{mm}$ merupakan range optimal dalam menghasilkan citra [9].

Citra satelit hasil penginderaan jauh terdiri atas resolusi rendah, resolusi menengah dan resolusi tinggi [10]. Dalam rangka pemanfaatan data CSRT secara optimal telah diatur dalam Instruksi Presiden Republik Indonesia Nomor 6 Tahun 2012 Tentang Penyediaan, Penggunaan, Pengendalian Kualitas, Pengolahan dan Distribusi Data Satelit Penginderaan Jauh Resolusi Tinggi [11]. Salah satu tugas Lembaga Penerbangan dan Antariksa Nasional (LAPAN) yaitu menyediakan data satelit penginderaan jauh resolusi tinggi dengan lisensi Pemerintah Indonesia. Selanjutnya, para pemangku kepentingan yang memerlukan data citra satelit dapat melakukan permintaan ke LAPAN dengan mekanisme tertentu.

\subsection{Spesifikasi CSRT}

Syarat citra satelit untuk pembuatan peta skala besar adalah sebagai berikut [7]:

1. Memiliki resolusi spasial lebih baik dari $\leq$ 0,65 meter, hal ini berarti bahwa untuk citra 1 piksel mewakili minimal 0,65 meter ukuran obyek fisiknya. Contoh gambaran resolusi spasial pada citra satelit diperlihatkan pada Gambar 1;

2. Harus dilengkapi dengan informasi parameter orbit satelit dan parameter sensor (dapat berupa parameter fisik orbit dan parameter fisik sensor atau RPC);

3. Tahun akuisisi citra satelit resolusi tinggi tidak lebih dari 2 tahun namun masih dapat dipertimbangkan menyesuaikan dengan kondisi dan perkembangan daerah;

4. Belum dilakukan koreksi geometrik;

5. Saat kondisi nadir (tegak lurus terhadap bumi) bahwa sudut pengambilan pada saat akuisisi data sebesar $\leq 20^{\circ}$; 
6. Setiap scene disyaratkan tutupan awan $\leq$ $10 \%$ dan tidak menutupi objek-objek penting.

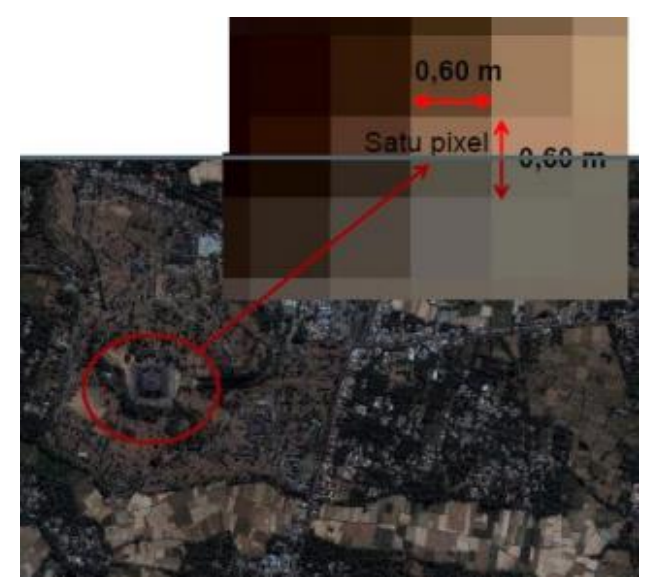

Gambar 1. Contoh (Penggambaran) Resolusi Spasial Pada Citra Satelit.

\subsection{Titik Kontrol Tanah}

Sudut pengambilan objek dari sensor satelit pada saat akuisisi data citra satelit dan adanya variasi topografi permukaan bumi, mempengaruhi kualitas posisi pada citra satelit yang dihasilkan. Semakin besar sudut pengambilan objek dari sensor satelit pada saat akuisisi maka makin besar kemungkinan pergeseran posisi terjadi. Semakin bervariasinya terrain/topografi (pegunungan dan perbukitan) semakin besar kemungkinan pergeseran posisi terjadi [12].

Koreksi geometrik atau biasa juga disebut sebagai orthorektifikasi diperlukan untuk meminimalisir kesalahan geometrik akibat sudut pengambilan obyek oleh sensor serta akibat perbedaan permukaan bumi (relief diplacement). Dalam proses orthorektifikasi planimetris diperlukan GCP (Ground Control Point), sehingga menghasilkan citra ground ortho planimetris [12].

\subsection{Desain Titik Kontrol Tanah (GCP)}

\subsubsection{Ketentuan Pemilihan Obyek GCP}

Objek untuk GCP memenuhi ketentuan sebagai berikut[13]:

1. Harus dapat diidentifikasi secara jelas dan akurat;

2. Harus berada pada permukaan tanah;

3. Bukan merupakan bayangan;

4. Tidak memiliki pola yang sama;
5. Permanen dan diam serta diyakini tidak akan mengalami perubahan atau pergeseran pada saat pengukuran GNSS;

6. Bentuk harus jelas dan tegas;

7. Warna harus kontras dengan warna disekitarnya;

8. Terdapat akses menuju lokasi GCP;

9. Bangunan dapat dipilih menjadi objek titik kontrol tanah dengan syarat adalah sebagai berikut:

a. Tidak ada objek lain selain bangunan ;

b. Bangunan konkrit, bukan bangunan sementara;

c. Ketinggian bangunan maksimal 3 meter dan bukan bangunan bertingkat;

d. Yang diukur merupakan sudut atap dan bukan sudut tembok bagian dalam bangunan.

Gambar 2 memperlihatkan contoh obyek untuk penentuan GCP.

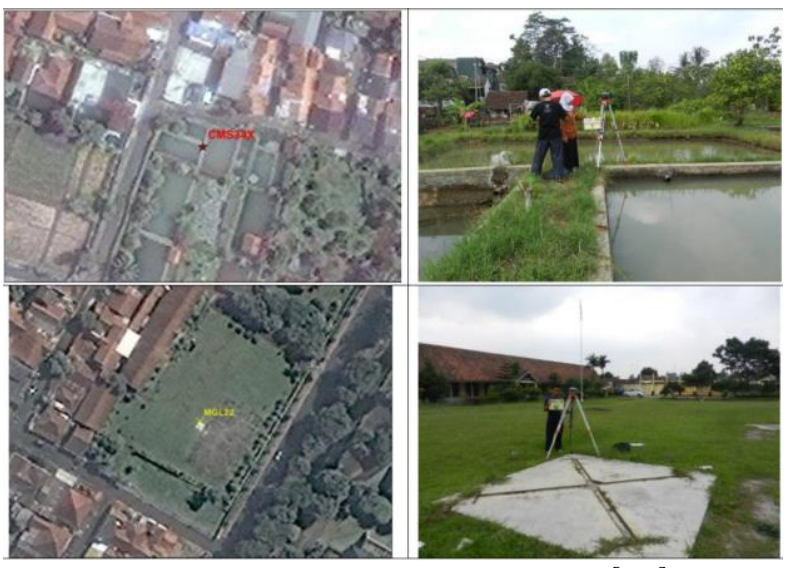

Gambar 2. Contoh Obyek Untuk GCP [13].

\subsubsection{Syarat Persebaran GCP}

Penentuan sebaran titik kontrol tanah harus pada sisi perimeter area citra; tengah area/scene; wilayah perbatasan/overlap scene citra; dan tersebar secara merata dalam area citra serta menyesuaikan kondisi terrain. Gambar 3 menunjukkan contoh desain persebaran GCP.

\section{METODE}

\subsection{Lokasi Penelitian}

Lokasi penelitian ini dilakukan di daerah yang disebut sebagai Pantai Gosong, Desa Sungai Raya, Kecamatan Sungai Raya 
Kepulauan, Kabupaten Bengkayang, Provinsi Kalimantan Barat. Adapun titik "nol” lokasi penelitian adalah pada koordinat $108^{0} 51^{\prime} 30^{\prime \prime} \mathrm{BT}$ - 108 53'20"BT, dan 0 43'48"LU - 042'10"LU, seperti yang terlihat pada Gambar 4.

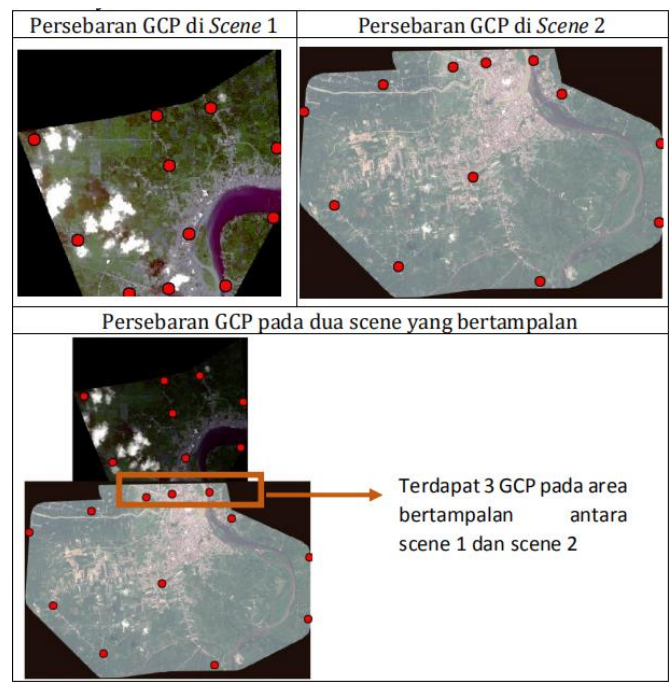

Gambar 3. Contoh Desain Persebaran GCP[13].

Gambar 4. memperlihatkan lokasi penelitian yang meliputi zona area tapak yaitu radius $1 \mathrm{~km}$ (site area) dan zona sekitar tapak yaitu radius $5 \mathrm{~km}$ (site vicinity) dengan luas lokasi penelitian keseluruhan sebesar 7.649 Ha yang meliputi wilayah perairan laut dan daratan. Secara administratif, lokasi penelitian mencakup 3 (tiga) wilayah desa di Kecamatan Sungai Raya Kepulauan, Kabupaten Bengkayang, Provinsi Kalimantan Barat, yaitu Desa Sungai Keran, Desa Sungai Raya dan Desa Karimunting.

\subsection{Data dan Peralatan}

Data yang digunakan pada penelitian ini, antara lain:

a) Citra satelit Pleiades 1A tahun 2018 dengan ketelitian pankromatik 0,5 $\mathrm{m}$ dan ketelitian multispektral $2 \mathrm{~m}$ di lokasi penelitian;

b) Sebaran titik koordinat ground control point (GCP) di lokasi penelitian;

c) Peta RBI Kabupaten Bengkayang;

d) Data kontur Kabupaten Bengkayang.

Sedangkan peralatan yang digunakan adalah:

a) High Performance Computer (HPC) untuk pengolahan dan analisa data citra satelit, spesifikasi: CPU i9 4,5 GHz, RAM 64 GB, GPU RTX 20808 GB Full HD 144 Hz;

b) Unit Komputer/Laptop untuk laporan;

c) GNSS Geodetik untuk survei dan pengukuran GCP, dengan spesifikasi sebagai berikut:

- Kanal sinyal treking = 572 kanal;

- Satelit treking = GPS, BeiDou, GLONASS, Galileo dan SBA;

- Akurasi RTK horisontal $=8 \mathrm{~mm}+$ 1ppm;

- Akurasi RTK vertikal $=15 \mathrm{~mm}+1 \mathrm{ppm}$;

- Akurasi horisontal pasca pengolahan = $2.5 \mathrm{~mm}+1 \mathrm{ppm}$

- Akurasi vertikal pasca pengolahan = $5 \mathrm{~mm}+1 \mathrm{ppm}$;

- Waktu inisialisasi $=$ kurang dari 10 detik.

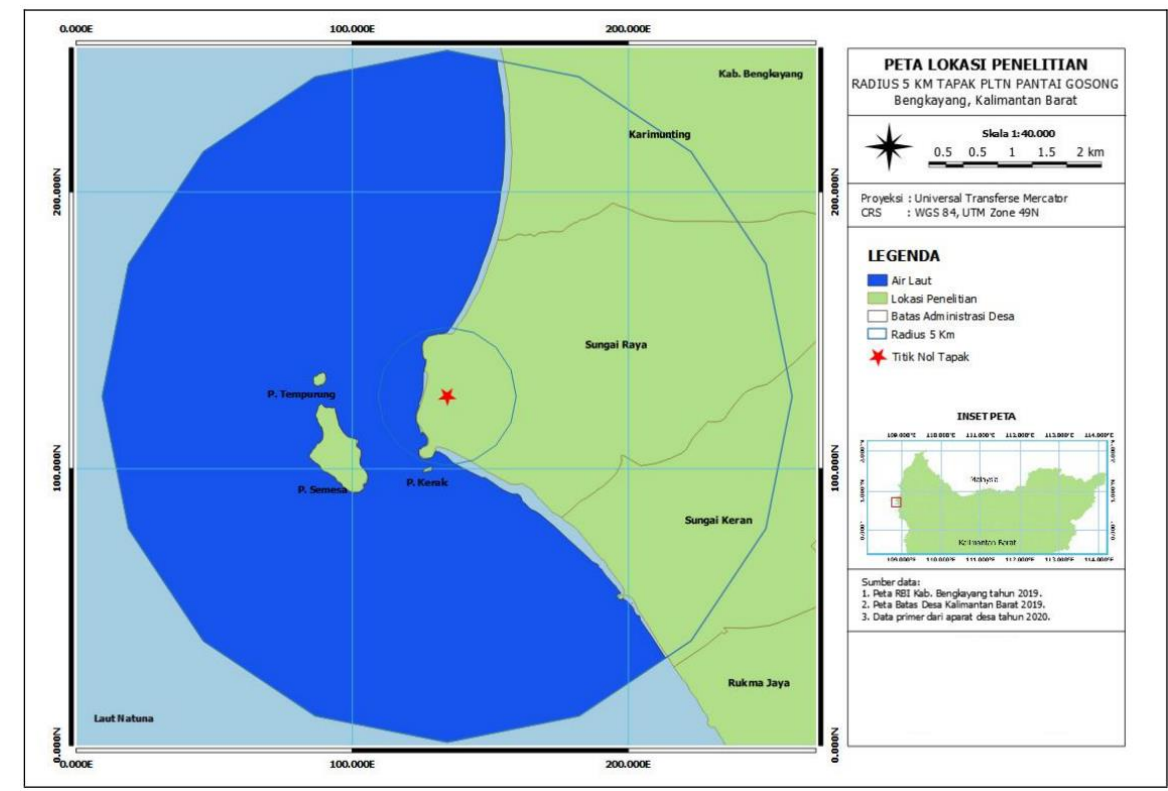

Gambar 4. Peta Lokasi Penelitian Radius 5 Km Tapak PLTN Kalimantan Barat. 


\subsection{Koreksi Geometrik}

Tahapan koreksi geometrik yang dilaksanakan adalah sesuai dengan diagram alir (flow chart) pada Gambar 5.:

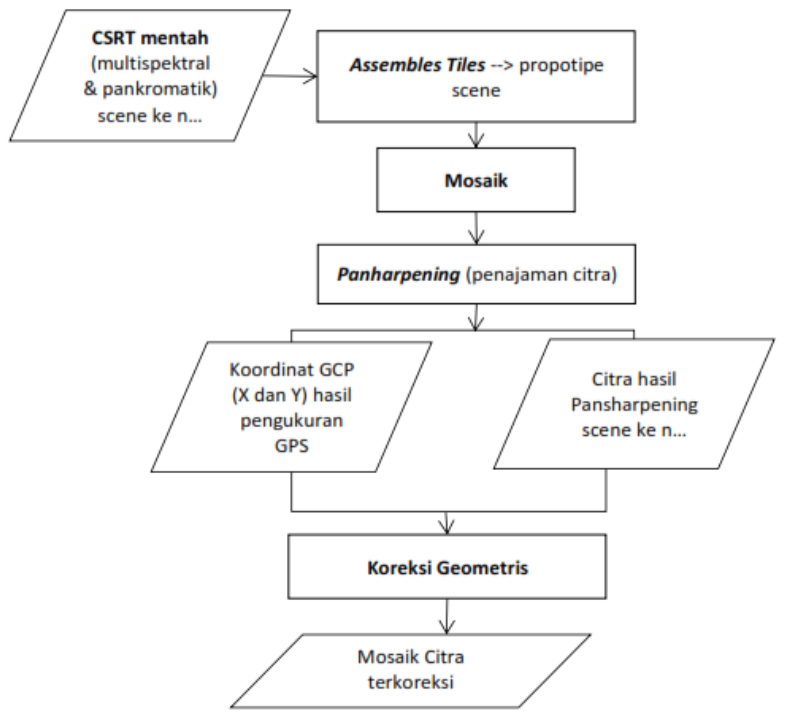

Gambar 5. Diagram Alir Koreksi Geometris.

Pengolahan data citra satelit dilakukan setelah pengukuran titik GCP (Ground Control Point) menggunakan GPS Geodetik. Inti dari pengolahan citra ini adalah melakukan koreksi koordinat $\mathrm{X}$ dan $\mathrm{Y}$ menggunakan hasil pengukuran titik GCP. Selanjutnya masingmasing tahapan pada gambar 5 dapat dijelaskan sebagai berikut [14]:

a) Assemble, untuk menghubungkan tile-tile citra sehingga membentuk prototipe satu scene data citra;

b) Mosaik citra, untuk menyatukan prototipe satu scene data citra menjadi scene citra yang utuh;

c) Pansharp, merupakan penajaman citra melalui penggabungan citra multispektral dan pankromatik. Proses ini bertujuan untuk memperbaiki mutu citra sehingga dapat dengan baik digunakan pada tahap selanjutnya, dengan pengolahan digital ataupun untuk interpretasi visual;

d) Processing data input GCP secara manual menggunakan titik kontrol tanah GCP;

e) Koreksi geometris dilakukan dengan masukan berupa data koordinat GCP hasil pengukuran dengan citra hasil proses pansharp (penajaman). Koreksi geometris dilakukan dengan cara mentransformasikan geometri (geo- referensi) atau unsur-unsur citra dijital sedemikian rupa, sehingga setiap piksel citra memiliki posisi di dalam sistem koordinat dunia nyata.

\section{HASIL DAN PEMBAHASAN}

\subsection{Evaluasi Spesifikasi CSRT}

Evaluasi spesifikasi dilakukan dengan cara mem-validasi data raster yang tersedia terhadap spesifikasi CSRT pada sub-bab 2.2. yang menjadi syarat-syarat pokok data raster tersebut dapat digunakan.

\begin{tabular}{|c|c|c|c|}
\hline Name & Date modified & Type & Size \\
\hline LIBRARY & 19/02/2020 11:50 & File folder & \\
\hline LINEAGE & 19/02/2020 11:50 & File folder & \\
\hline MASKS & 19/02/2020 11:50 & File folder & \\
\hline DIM_PHR1A_MS_201507030317405_SEN_... & 23/10/2015 15:05 & XML Document & $97 \mathrm{~KB}$ \\
\hline - ICON_PHR1A_MS_201507030317405_SEN... & $23 / 10 / 201515: 04$ & JPG File & $28 \mathrm{~KB}$ \\
\hline IMG_PHR1A_MS_201507030317405_SEN_... & 23/10/2015 15:05 & TFW File & $1 \mathrm{~KB}$ \\
\hline IMG_PHR1A_MS_201507030317405_SEN_... & 23/10/2015 15:05 & TIF File & $1,102,939 \mathrm{~KB}$ \\
\hline [IIMG_PHR1A_MS_201507030317405_SEN_... & 23/10/2015 15:04 & TFW File & $1 \mathrm{~KB}$ \\
\hline IMG_PHR1A_MS_201507030317405_SEN_... & 23/10/2015 15:04 & TIF File & $184,016 \mathrm{~KB}$ \\
\hline C INDEX & 23/10/2015 15:04 & Microsoft Edge H... & $20 \mathrm{~KB}$ \\
\hline ه PREVIEW_PHR1A_MS_201507030317405_S... & 23/10/2015 15:04 & JPG File & $694 \mathrm{~KB}$ \\
\hline PREVIEW_PHR1A_MS_201507030317405_S... & 23/10/2015 15:05 & KMZ & $753 \mathrm{~KB}$ \\
\hline RPC_PHR1A_MS_201507030317405_SEN_... & 23/10/2015 15:04 & XML Document & $13 \mathrm{~KB}$ \\
\hline
\end{tabular}

Gambar 6. Susunan File Citra Pleiades.

Adapun proses validasi citra Pleiades dilakukan dengan cara mencermati dengan seksama file DIM yang berekstensi .XML (Gambar 6) yang dapat dibuka dengan aplikasi pengolah kata sebagai berikut:

a) Validasi resolusi spasial seperti diperlihatkan pada Gambar 7.

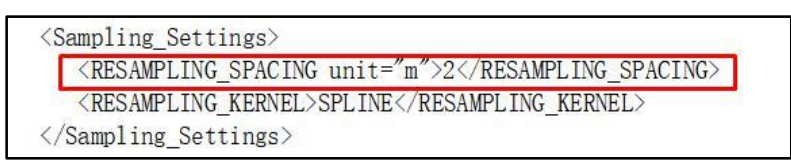

(a)

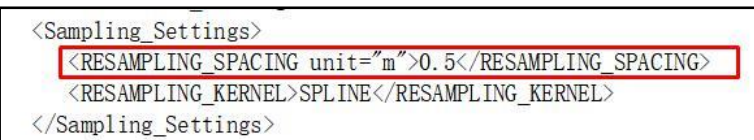

(b)

Gambar 7. Identifikasi Resolusi Spasial Citra Pleiades: (a) Multispektral (2 m); (b) Pankromatik (0.5 m).

b) Validasi tahun akuisisi data dan sudut pengambilan seperti diperlihatkan pada Gambar 8. Kotak bertanda merah menunjukkan informasi tahun akuisisi dan sudut pengambilan data. 


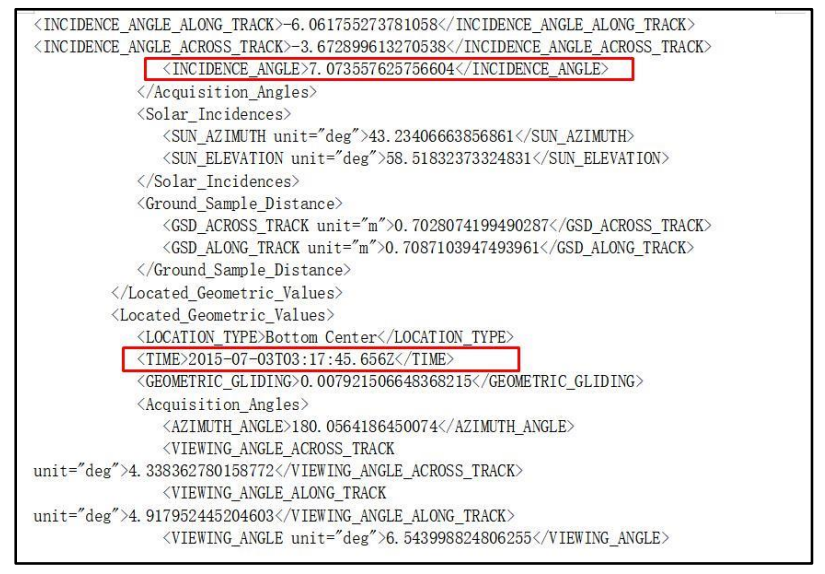

Gambar 8. Tahun Akuisisi dan Sudut Pengambilan.

c) Validasi penggunaan tutupan awan (cloud cover). Gambar 9 menunjukkan prosentase tutupan awan.

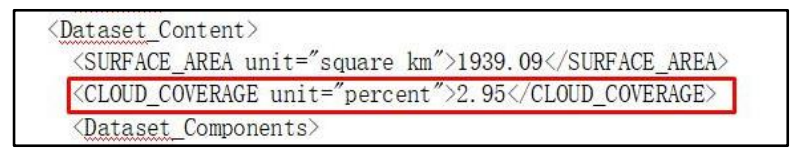

Gambar 9. Tutupan Awan.

\subsection{Assemble, Mosaik dan Pansharp}

Gambar 10 memperlihatkan citra Pleiades tahun 2018 yang telah mengalami proses mosaik dan penajaman citra (pansharp). Pada kedua gambar tersebut dapat terlihat perbedaan yang nyata antara data citra Pleiades multispektral asli, yang belum mengalami proses penggabungan warna (color merger) dengan citra Pleiades pankromatik ataupun belum mengalami proses penajaman citra.

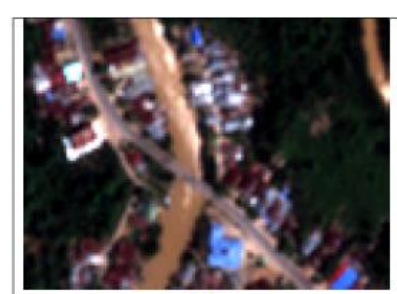

(a)

Keterangan:

a) Citra Pleiades multispektral resolusi 2 meter;

b) Citra Pleiades pankromatik mosaik resolusi 0,5 meter;

c) Citra Pleiades hasil

penajaman/pansharp resolusi 0,5 meter.
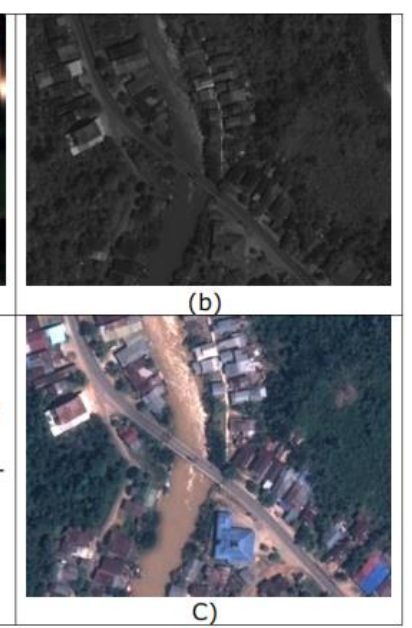

C)
Sebelum proses penajaman citra, citra Pleiades pankromatik untuk lokasi penelitian terdiri dari 2 tiles, sehingga harus dilakukan proses assemble tiles sebelum diproses mosaik

\subsection{Koreksi Geometrik}

Koreksi geometrik yang biasanya dilakukan adalah koreksi geometrik sistematik dan koreksi geometrik presisi. Koreksi geometrik sistematik merupakan koreksi yang dilakukan dengan menggunakan informasi karakteristik sensor yaitu orientasi internal (internal orientation) [5]. Koreksi geometrik sistematik dilakukan oleh pihak yang mengeluarkan data (data provider) tersebut dan hasil koreksi diberikan. Koreksi geometrik presisi merupakan cara untuk memperbaiki kualitas geometrik data citra dengan menggunakan GCP [5].

\subsubsection{Hasil pengukuran GCP}

Pengukuran GCP dilakukan terpencar dan menyebar pada citra, sehingga perhitungan rektifikasi tidak bertumpuk pada salah satu sudut saja. Gambar 11 menunjukkan sebaran titik GCP hasil pengukuran. Selain hal tersebut, sebaran titik kontrol yang menyebar merata di permukaan citra agar [15]:

a. Fungsi transformasi digunakan pada distorsi yang bersifat acak (random);

b. Transformasi koordinat dapat dinyatakan dengan persamaan polinomial mulai dari orde terendah hingga orde tinggi.

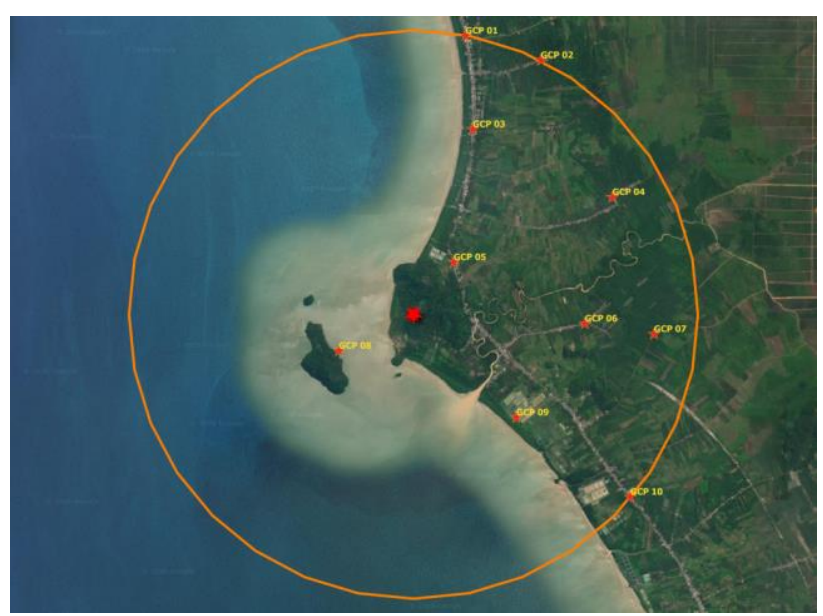

Gambar 11. Sebaran Titik GCP Hasil Pengukuran. 


\subsubsection{Koreksi Geometrik on Screen}

Selanjutnya proses koreksi geometrik dilakukan dengan tools perangkat lunak QGIS dimana proses ini menghasilkan citra (pansharp) yang ter-georeferensi dengan 10 (sepuluh) titik GCP hasil pengukuran lapangan. Citra sebelum dan sesudah proses georeferensi atau koreksi geometrik diperlihatkan pada Gambar 12.

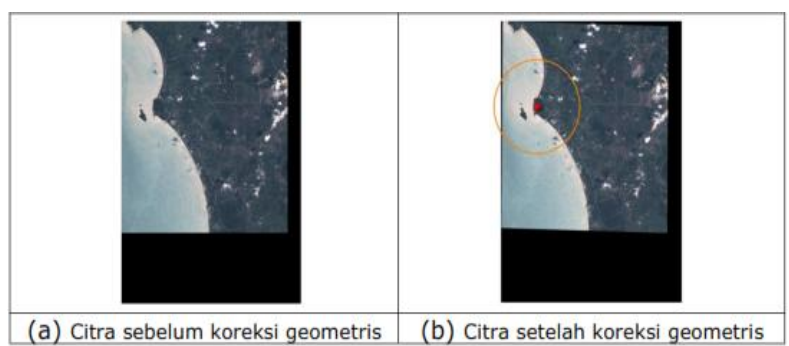

Gambar 12. Perbandingan Citra Pleiades 2018.

Gambar 13 berikut menunjukkan Citra pleiades tahun 2018 dengan deliniasi lokasi penelitian. Citra pleiades tersebut merupakan data raster terkoreksi sebagai luaran akhir proses koreksi geometrik. Sebagai langkah terakhir data raster terkoreksi geometrik akan diuji untuk membuktikan bahwa data tersebut layak digunakan sebagai dasar pembuatan data vektor yang dibutuhkan.

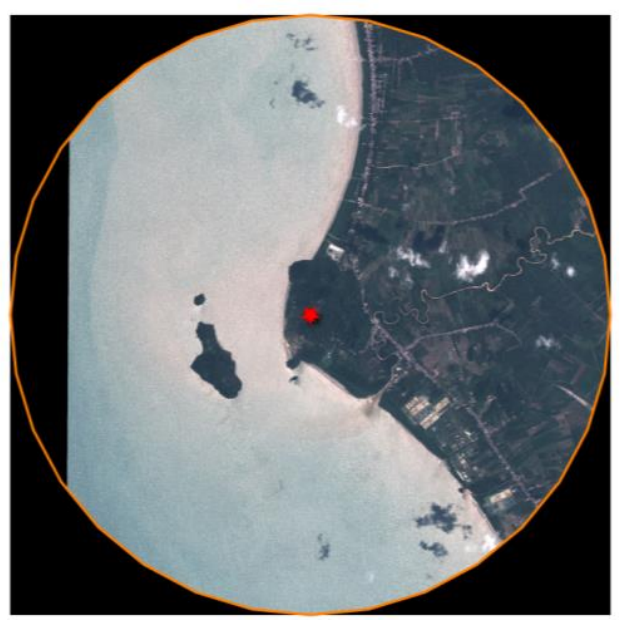

Gambar 13. Data Raster Terkoreksi Geometrik Delineasi Lokasi Penelitian.

\subsubsection{Uji Akurasi Ketelitian Geometrik}

Nilai ketelitian citra Satelit yang telah mengalami orthorektifikasi dapat dilakukan dengan uji akurasi/ketelitian Geometri. Akurasi diukur dengan menggunakan root mean square error (RMSE) atau circular error. Perlu diperhitungkan adalah koordinat (X, Y) titik uji dan posisi sebenarnya di lapangan [16].

Sumber data peta RDTR pada Citra Satelit Resolusi Tinggi dikatakan memenuhi standar ketelitian peta dasar skala 1:5000 apabila akurasi ketelitian horizontal $\leq 2,5$ meter (kelas 3) [5][17-20].

Tabel 1. Ketelitian Peta RBI Kelas 3 [5].

\begin{tabular}{ccccc}
\hline No & Skala & $\begin{array}{c}\text { Interval } \\
\text { kontur }\end{array}$ & $\begin{array}{c}\text { H+ (CE90 } \\
\text { dalam m) }\end{array}$ & $\begin{array}{c}\text { V+ (LE90 } \\
\text { dalam m) }\end{array}$ \\
\hline 1 & $1: 250.000$ & 100 & 125 & 125 \\
2 & $1: 100.000$ & 40 & 50 & 50 \\
3 & $1: 50.000$ & 20 & 25 & 25 \\
4 & $1: 25.000$ & 10 & 12,5 & 12,5 \\
5 & $1: 10.000$ & 4 & 5 & 5 \\
6 & $1: 5000$ & 2 & 2,5 & 2,5 \\
7 & $1: 2500$ & 1 & 1,25 & 1,25 \\
8 & $1: 1000$ & 0,4 & 0,5 & 0,5 \\
\hline
\end{tabular}

Ketelitian geometri tersebut dihitung berdasarkan pada Peraturan Kepala BIG Nomor 15 Tahun 2014 tentang Pedoman Teknis Ketelitian Peta Dasar. Perhitungan akurasi hasil orthorektifikasi, menggunakan nilai CE90 yang dihitung dari nilai RMSE resolusi citra satelit setelah diorthorektifikasi. Nilai akurasi horisontal dengan tingkat kepercayaan pada level 90\% (NSSDA), sesuai dengan Persamaan 1 [19].

Accuracy $_{r}=-1,5175 \times R M S E_{r}$

Seperti hasil perhitungan yang diperlihatkan pada Tabel 2 RMSE $_{\mathrm{r}}$ yang dihasilkan sebesar 1,52967195 (dibulatkan 1,53) sehingga nilai akurasi horisontal citra satelit resolusi tinggi (Citra pleiades 2018) adalah sebesar 2,321277184 (dibulatkan 2.32).

\section{KESIMPULAN}

Ketersediaan citra satelit Pleiades dengan resolusi tinggi merupakan salah satu sumber data utama yang digunakan pada penelitian ini. Adapun kesimpulan dari hasil penelitian ini adalah sebagai berikut:

1) Data raster berupa citra Pleiades 2018 yang digunakan sebagai sumber data utama pada penelitian ini, berhasil dilakukan penajaman pada area of interest (AOI) wilayah penelitian; 
Tabel 2. Hasil Perhitungan RMSE Pada Uji Akurasi Koreksi Geometrik Citra Pleiades 2018.

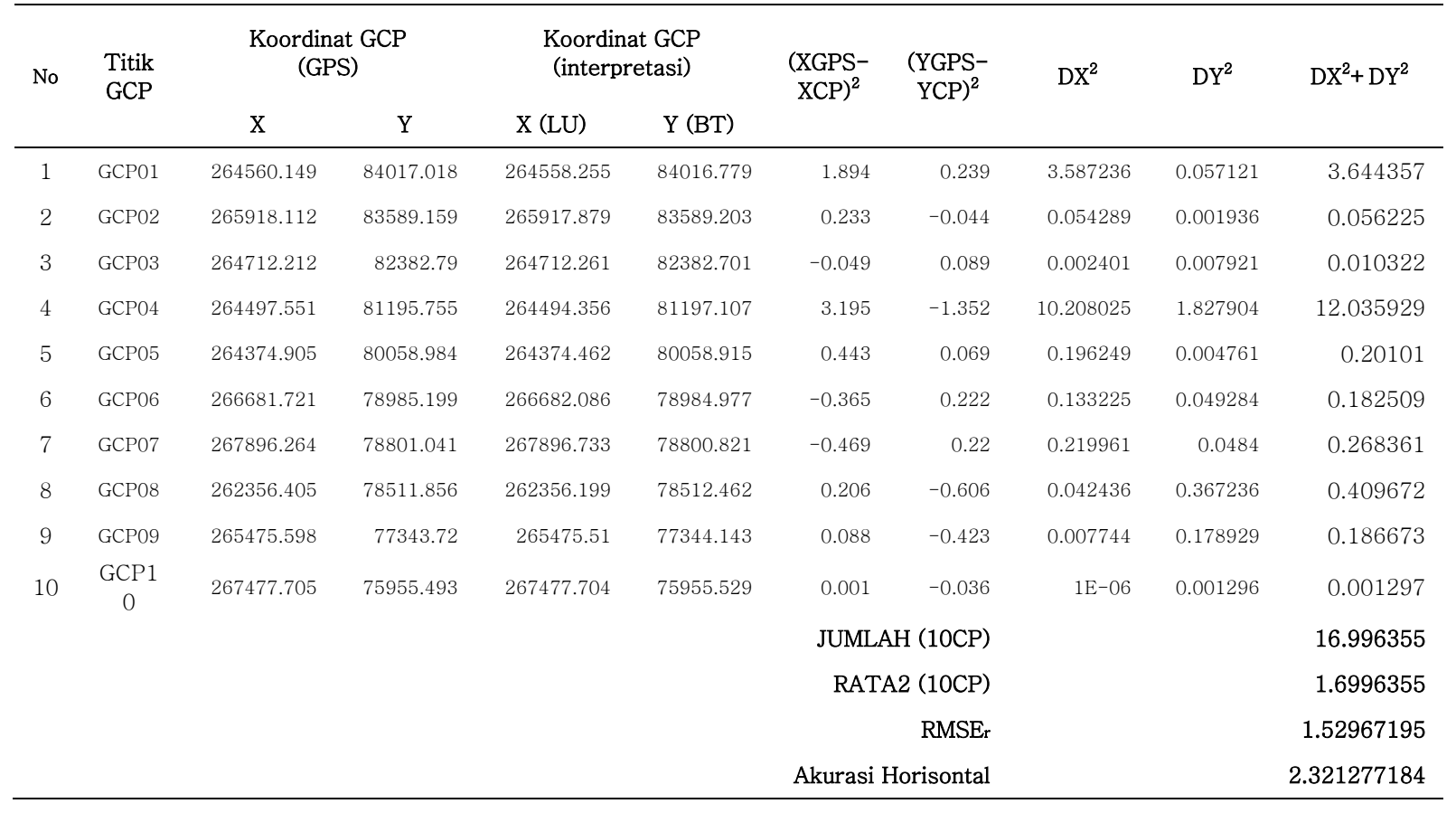

2) Pembetulan atau pemulihan geometri beserta koordinat citra Pleiades 2018 dengan AOI wilayah penelitian berhasil dilakukan dengan RMSE $_{\text {rror }}$ sebesar 1,53 sehingga akurasi horisontal yang dicapai sebesar 2,32;

3) Citra Pleiades 2018 hasil koreksi geometrik, dapat digunakan untuk pembuatan peta dasar tata guna lahan dengan skala 1:5.000.

\section{UCAPAN TERIMA KASIH}

Ucapan terima kasih dihaturkan kepada PKSEN-BATAN yang telah mendukung pendanaan untuk pelaksanaan penelitian ini serta semua pihak yang telah membantu terlaksananya penelitian ini.

\section{DAFTAR ACUAN}

[1] BAPETEN, 2018, "Peraturan Badan Pengawas Tenaga Nuklir No. 4 Tahun 2018 tentang Ketentuan Keselamatan Evaluasi Tapak Instalasi Nuklir”, Badan Pengawas Tenaga Nuklir, Jakarta.

[2] Heni S., "Penentuan Tapak Potensial PLTN dengan Metode SIG di Wilayah Pesisir Propinsi Kalimantan Barat", Jurnal Pengembangan Energi Nuklir Vol. 16 No. 2, 2014, halaman 132.
[3] Mudjiono, Siti A., Heni Susiati, "Identifikasi Perubahan Tata Guna Lahan di Sekitar Calon Tapak PLTN Kabupaten Bengkayang, Kalimantan Barat”, Jurnal Pengembangan Energi Nuklir, Volume 22, No. 2, 2020, halaman $101-110$.

[4] Bambang S., "Dampak Pembangunan PLTN Terhadap Perubahan Tata Ruang Kabupaten Jepara”, GEMA TEKNOLOGI, Vol. 16 No.1, 2010.

[5] F. Sri H. P., dkk, 2015, Aplikasi Penginderaan Jauh Sistem Informasi Geografis untuk Pengembangan Wilayah, Kampus Polimedia, Jakarta - Jakarta Selatan.

[6] Reza L., Endi H.P., Meilinda A., 2019, "Standar Koreksi Geometrik Citra Satelit Resolusi Menengah dan Manfaat Bagi Pengguna”, Pusat Penelitian dan Pengembangan Standardisasi, Badan Standardisasi Nasional, Jakarta.

[7] Pusat Pemetaan Tata Ruang - BIG, 2019, Modul 2: Sumber Data Peta RDTR dan Desain Titik Kontrol Tanah, BIG - Cibinong.

[8] I.K. Arimbawa, Khomsin, "Kajian Bebagai Macam Citra Satelit Terhadap Skala Peta (Planimetris)", GEOID Vol. 5 No. 01, Agustus 2009 (055-058).

[9] H.T. Setyawan., Suryono. "Uji Resolusi Spasial pada Perangkat Lunak Computed Radiography Menggunakan Pengolahan Citra Digital ". Youngster Physics Journal, Vol. 3, No. 4, Oktober 2014, hal 311 - 316;

[10] Menteri Hukum dan HAM RI, Undang-Undang Republik Indonesia No. 21 Tahun 2013 Tentang Keantariksaan, Lembaran Negara Republik Indonesia Tahun 2013 Nomor 133.

[11] Sekretariat Kabinat RI, 2012. "Instruksi Presiden Republik Indonesia No. 6 Tahun 2012 Tentang Penyediaan, Penggunaan, Pengendalian Kualitas, Pengolahan dan Distribusi Data Satelit Penginderaan Jauh Resolusi Tinggi”, Sekretariat Kabinet RI, Deputi Bidang Kesejahteraan Rakyat. 
[12] Eli Juniati, Harintaka. "Perbandingan Ragam Input Model Ketinggian untuk Pembentukan TrueOrthophoto di Area Urban”. GEOMATIKA, Vol. 24, No. 2, November 2018.

[13] Pusat Pemetaan Tata Ruang - BIG, 2019, "Modul 1: Pengantar Pemetaan Rencana Detail Tata Ruang ”, 2019, BIG, Cibinong.

[14] Fadila M., Hendayani, Sukentyas E. S., Tuti G., Atrion J., "Pengembangan Standardisasi Metode Koreksi Geometrik Data Optik Satelit Penginderaan Jauh Resolusi Menengah”, Seminar Nasional Penginderaan Jauh Ke-4 Tahun 2017.

[15] Achmad R., A., A., "Optimasi Sebaran Titik GCP dan ICP pada Proses Ortorektifikasi Citra Resolusi Tinggi untuk Pembuatan Peta Skala 1:5000 (Studi Kasus: 1 Scene Citra Pleiades 033 Lumajang), Jurusan Teknik Geomatika, Fakultas Teknik Sipil dan Perencanaan, Institut Teknologi Sepuluh Nopember, Surabaya, 2017.

[16] Pusat Pemetaan Tata Ruang - BIG, 2019 "Modul Validasi Peta Rencana Detail Tata Ruang", Cibinong.

[17] BIG, 2018, "Spesifikasi Teknis Peta Dasar Untuk Penyusunan Rencana Detail Tata Ruang”, Cibinong.

[18] BIG, 2018, "Spesifikasi Teknis Peta Dasar Untuk Penyusunan Rencana Detail Tata Ruang”, Cibinong,

[19] BIG, 2014, "Peraturan Kepala Badan Informasi Geospasial Nomor 15 Tahun 2014 tentang Pedoman Teknis Ketelitian Peta Dasar", Cibinong.

[20] Ari Z., F., "Analisis Ketelitian Orthorektifikasi Citra Pleiades dan Spot6 Untuk Pembuatan Peta Dasar RDTR Pesisir (Studi Kasus: Kecamatan Kenjeran, Surabaya)". Tugas Akhir, Jurusan Teknik Geomatika, Fakultas Teknik Sipil dan Perencanaan, Institut Teknologi 10 Nopember, Surabaya 2016. 